\title{
UNDERSTANDING THE DYNAMICS OF THE BRAZILIAN MARKET FOR NATIVE FOREST WOOD: A CASE STUDY FOR MINAS GERAIS STATE, BRAZIL
}

Thales Guilherme Vaz Martins $2^{2 *}$, Geraldo Gonçalves dos Reis ${ }^{3} \odot$, Maria das Graças Ferreira Reis ${ }^{3} \bullet$, Rodrigo Vieira Leite ${ }^{2}$,Lucas Arthur de Almeida Telles ${ }^{2} \odot$, Gleidson Guilherme Caldas Mendes ${ }^{2} \odot$, Mayara $^{\circ}$

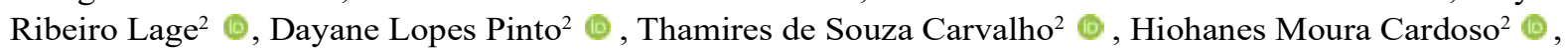

Alexandre Simões Lorenzon ${ }^{3} \odot$ and Douglas Vinícius Vaz Martins ${ }^{4}$ ()

\footnotetext{
${ }^{1}$ Received on 10.12.2020 accepted for publication on 01.04.2021.

${ }^{2}$ Universidade Federal de Viçosa, Programa de Pós-Graduação em Ciência Florestal, Viçosa, MG - Brasil. E-mail: <thales.eng.florestal@ gmail.com>, <rodrigo.leite@ufv.br>,<lucasarthur36@gmail.com>, <gmendesflorestal@gmail.com>, <mayararlage@hotmail.com>, $<$ dayanelopesp@gmail.com>,<dsc.thamires@gmail.com> and <hiohanes.cardoso@gmail.com>.

${ }^{3}$ Universidade Federal de Viçosa, Departamento de Engenharia Florestal, Viçosa, MG - Brasil. E-mail: <greisufv@gmail.com>,<mgfreis@ ufv.br> and <aleslorenzon@gmail.com>.

${ }^{4}$ Laboratório Nacional de Astrofísica, Itajubá, MG - Brasil. E-mail: <dmartins@lna.br>.

*Corresponding author.
}

\begin{abstract}
Understanding the Brazilian market for native wood helps forest managers and can guide conservation policies. This study aimed to evaluate the spatial and temporal distribution of supply and demand of the Brazilian native wood for four products namely, charcoal, roundwood, firewood, and sawn wood. We used the consumed wood volume from 2006 to 2016 in Minas Gerais (MG) tracking its supplier in Brazil accounting for 31 million cubic meters. These data were used as input for calculating mean centers and performing grouping analysis. The wood supply centers for the energy sector in Brazil have moved from Cerrado to the Caatinga biome. This change is consistent with historical patterns of agricultural expansion in Brazil. The largest mesoregions producing wood were: East of Mato Grosso do Sul State, South of Goiás State, and Center-South of Bahia State. The solid wood supply centers have moved from the North to Midwest regions but remained within the Amazon biome for almost all the years. This pattern is likely a consequence of timber regulation practices in the Amazon. The mesoregions: Madeira-Guaporé and East of Rondônia State, Southeast and Northeast of Pará State, and North of Mato Grosso State were the most important suppliers of solid wood to MG. Wood consumption for energy is centered in the Center and North regions of MG State, especially in Sete Lagoas, a hub of pig iron and cement industries. Solid wood products are dispersed in MG State, being Belo Horizonte, Conselheiro Lafaiete, Ubá, and Uberlândia the distribution centers of native wood for the furniture industry within MG. The spatial statistics helped to exploit the activity of the native wood market in Brazil and provides essential information for decision-makers that was not previously available.
\end{abstract}

Keywords: Brazilian wood market; Tropical forest; Spatial statistics.

\section{ENTENDENDO A DINÂMICA DO MERCADO BRASILEIRO DE MADEIRA DE FLORESTA NATIVA: UM ESTUDO DE CASO PARA O ESTADO DE MINAS GERAIS, BRASIL}

\begin{abstract}
RESUMO - Entender o mercado brasileiro de madeira nativa auxilia os gestores florestais e pode orientar as políticas de conservação. Este estudo teve como objetivo avaliar a distribuição espacial e temporal da oferta e demanda da madeira nativa brasileira para quatro produtos: carvão vegetal, madeira em tora, lenha e madeira serrada. Foi utilizado o volume de madeira consumido de 2006 a 2016 em Minas Gerais (MG) totalizando 31 milhões de metros cúbicos e obtido seu fornecedor no Brasil. Esses dados foram usados como entrada para calcular os centros médios e realizar análises de agrupamento. Os centros de abastecimento de madeira para o setor de energia no Brasil passaram do bioma Cerrado para a Caatinga. Essa mudança é consistente com os padrões históricos de expansão agrícola no Brasil. As maiores mesorregiões produtoras de madeira foram: Leste de Mato Grosso do Sul, Sul de Goiás e Centro-Sul da Bahia. Os centros de abastecimento de madeira
\end{abstract}

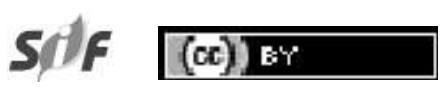

Revista Árvore 2021;45:e4518

http://dx.doi.org/10.1590/1806-908820210000018 
sólida mudaram-se das regiões Norte para Centro-Oeste, mas permaneceram no bioma Amazônia por quase todos os anos. Esse padrão é provavelmente uma consequência das práticas de regulamentação da madeira na Amazônia. As mesorregiões: Madeira-Guaporé e Leste do Estado de Rondônia, Sudeste e Nordeste do Pará e Norte do Mato Grosso foram os principais fornecedores de madeira maciça para MG. O consumo de madeira para energia está concentrado nas regiões Centro e Norte do Estado de MG, principalmente em Sete Lagoas, polo das indústrias de ferro-gusa e cimento. Os produtos de madeira maciça estão dispersos no Estado de MG, sendo Belo Horizonte, Conselheiro Lafaiete, Ubá e Uberlândia os centros de distribuição de madeira nativa para indústria moveleira de MG. As estatísticas espaciais ajudaram a explorar a atividade do mercado de madeira nativa no Brasil e fornecem informações essenciais para os tomadores de decisão que não estavam disponiveis anteriormente.

Palavras-Chave: Mercado brasileiro de madeira; Floresta tropical; Estatística espacial.

\section{INTRODUCTION}

The Brazilian native wood market incorporates multiple ventures hold different positions in the production chain, varying in structure and capacity, but dependent of a common natural resource: the wood (Kies et al., 2009; Canova and Hicley, 2012; Köhl et al., 2015; Bösch et al., 2015). In order to maintain a continuous flow of wood and other forestderived benefits, it is essential to understand market dynamics and nuances shaping relationships between the native wood supply and demand (Syrbe and Walz, 2012).

The wood supply depends on forest biophysical conditions and the potential changes imposed to its structure, which may have anthropic or natural causes. If wood supply significantly decreases, companies and society`s demands may not be met (Burkhard et al., 2012). On the other hand, the status of a forest depends not only on its ability to supply wood but also on society's needs (Paetzold et al., 2010). In this context, variation in the human desired level of provision, increases or decreases the demand for wood and other forest products, impacting economic factors, policies, among others (Curran and de Sherbinin, 2004).

Transport wood over long distances, which may also increase its price, contributes to the existence of a geographical discrepancy between supply and demand regions (Syrbe and Walz, 2012). This trend is typical in Brazil, where consumer centers are mainly located in the southeast part of the country, considerably distant from the supplier regions, often located in the Amazon Region (IBAMA, 2014; IBGE, 2018). As a consequence, harvest environmental impacts are perceived in places far from the large population centers (Burkhard et al., 2012). Identifying regions that are being over explored for wood provision would help to guarantee a continuous flow of supply. These specific areas need to be conserved and managed according to their productive potential (Van Jaarsveld et al., 2005).

Due to this spatial characteristic of the native wood market, mapping supply and demand distributions and its changes over time potentially provide direct measures of the human activity over the ecosystem (Burkhard et al., 2012). This visualization can be used to support decision-making concerning conservation policies and to allocate production resources in order to take market opportunities as advantage (Martins et al., 2018). Unfortunately, this type of research is rare in Brazil and the scientific and political challenges that arise require innovative responses and approaches.

Wood-based industries tend to be clustered on specific regions, forming networks and regional production centers (Bösch et al., 2015) that may vary through time and space. Spatial statistics tools can include the spatial component of the native wood market and provide a better understanding about supply and demand, revealing not only changes but also its trends (Kies et al., 2009). In this perspective, this study investigates the spatial and temporal dynamics regarding supply and demand of native wood in Brazil, from 2006 to 2016, considering Minas Gerais State (MG), the second-largest consumer of native wood in the country, as the demand center.

\section{MATERIAL AND METHODS}

\subsection{Data acquisition}

Data of native wood consumption in $\mathrm{MG}$ State, from 2006 to 2016, were compiled from the DOF System (Document of Forest Origin), based on "Portaria MMA no 253/2006" published in

Revista Árvore 2021;45:e4518 
08/18/2006. This document carries information about the commercialization and legal transport of native forests resources in Brazil since 2006. It includes wood origin in the country and destination all over MG State for energy-related (charcoal and firewood) and solid wood products (roundwood and sawn wood). Origins and destinations were imported into GIS environment, ArcGIS ${ }^{\circledR}$ 10.6.1 software (ESRI - Redlands, CA, USA). Records were manually checked for quality control in order to ensure information fidelity when creating the geospatial database with 770,413 records (Figure 1).

\subsection{Spatial analysis}

The Brazilian geographic space was divided according to administrative limits of its mesoregions, in order to analyze the wood origin in the entire country and its destination in municipalities of MG State (Figure. 1). Data spatial pattern was analyzed using two spatial statistics: (1) mean center and (2) grouping analysis. The first one gives a measure of
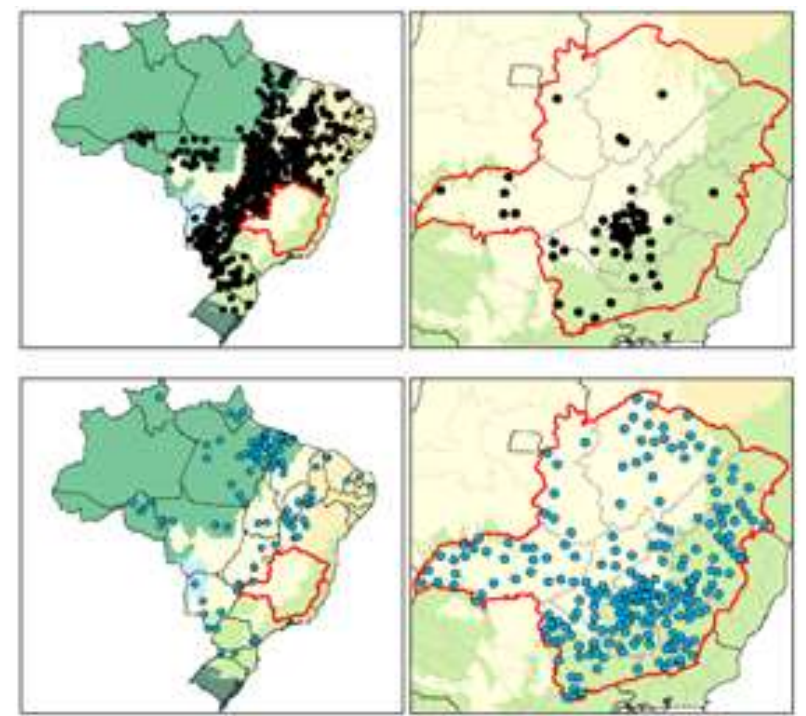

\section{Products}

- Charcoal - Roundwood Biome

$\begin{array}{llr}\text { Amazónia } & \text { Pantanal } \\ \text { Mata Atlântica } & \text { Cerrado } & \square \text { States } \\ \text { Pampa } & \text { Caatinga } & \text { Mesoregions }\end{array}$

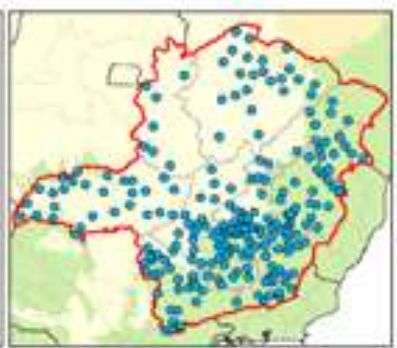

spatial central tendency, while the second one a measure of spatial autocorrelation.

\subsubsection{Mean center}

Mean center, or centroid, (Hart, 1954; Yue et al., 2003; Wang et al., 2010; Ayhan e Cubukcu, 2010; Arima et al., 2011; Lausch et al., 2013; Martins et al., 2018) is a statistic that presents only the data tendency and not the exact point of the greatest value. The main applications refer to analyzing spatiotemporal change patterns measured by the central tendency value. For this reason, the weighted mean center was used with wood volume as the weighting factor. The model is defined as (Equation 1):

$$
\left(\bar{X}_{w} ; \bar{Y}_{w}\right)=\sum_{i=1}^{n} w_{i} x_{i} / \sum_{i=1}^{n} w_{i} ; \sum_{i=1}^{n} w_{i} y_{i} / \sum_{i=1}^{n} w_{i} \text { 'Eq. } 1
$$

where $\left(\overline{\mathrm{X}}_{\mathrm{w}} ; \overline{\mathrm{Y}}_{\mathrm{w}}\right)$ are the weighted mean center coordinates; $x_{i}$ and $y_{i}$ are the coordinates of the feature $i ; n$ is the number of features; $w_{i}$ is the weight of the feature $i$.
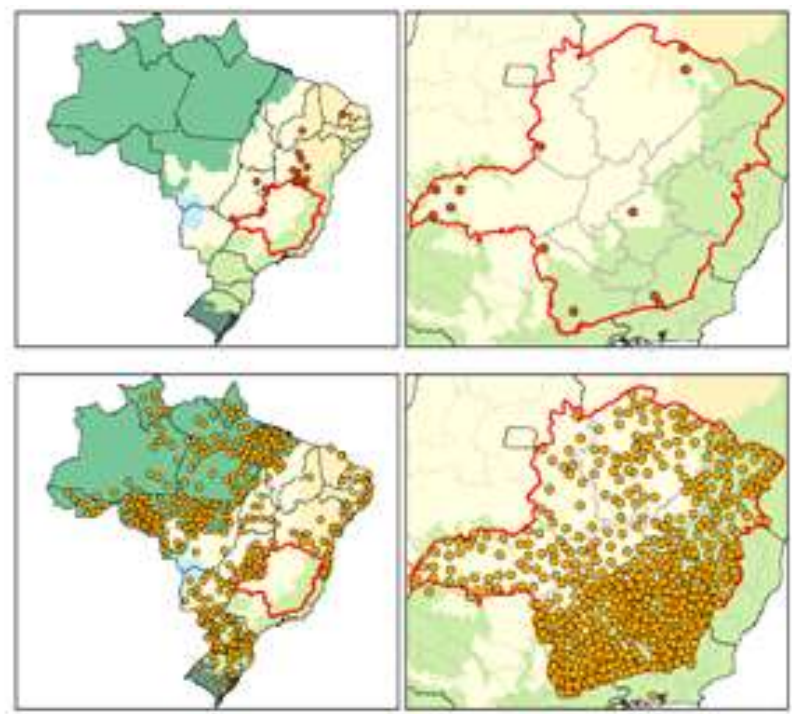

Proję̧lo Cónica de Albets Datum: SIRGAS 2000 Meridiano Central : -55 Latitude de Origem: -35 Paralclo Padrilo 1: -1 Paralclo Padrabo 2:-27

Figure 1 - Spatial distribution of native wood origin in Brazil and its destination in Minas Gerais State, from 2006 to 2016 . Compiled from: http://ibama.gov.br/flora-e-madeira/dof/relatorios-dof\#info-transporte.

Figura 1 - Distribuição espacial da origem da madeira nativa no Brasil e seu destino no Estado de Minas Gerais, de 2006 a 2016. Compilado de: http://ibama.gov.br/flora-e-madeira/dof/relatorios-dof\#info-transporte. 
Weighted mean center of wood origin and destination were calculated for each year of investigation (2006 to 2016), based on the wood volume $\left(\mathrm{m}^{3}\right)$ for each mesoregion and municipality, respectively.

\subsubsection{Grouping analysis}

Grouping analysis identifies similarity or divergence between sampling units from different spatially defined locations and separates statistically different clusters (Wu et al., 2015). This analysis was done based on wood volume for each category (charcoal, firewood, roundwood and sawnwood) and by using the Euclidean distances between features, without a maximum distance threshold. Four groups were created: very high, high, moderate and low. $\mathrm{R}^{2}$ was calculated to show data variation and grouping accuracy (Equation 2 to 4 ).

$$
R^{2}=(S S T-S S E) / S S T,
$$

Where $S S T$ represents the difference between groups and $S S E$ is the similarity within a group (Equation 3 and 4):

$S S T=\sum_{i=1}^{n_{c}} \sum_{j=1}^{n_{i}} \sum_{k=1}^{n_{v}}\left(V_{i j}^{k}-\overline{V^{k}}\right)^{2}$,
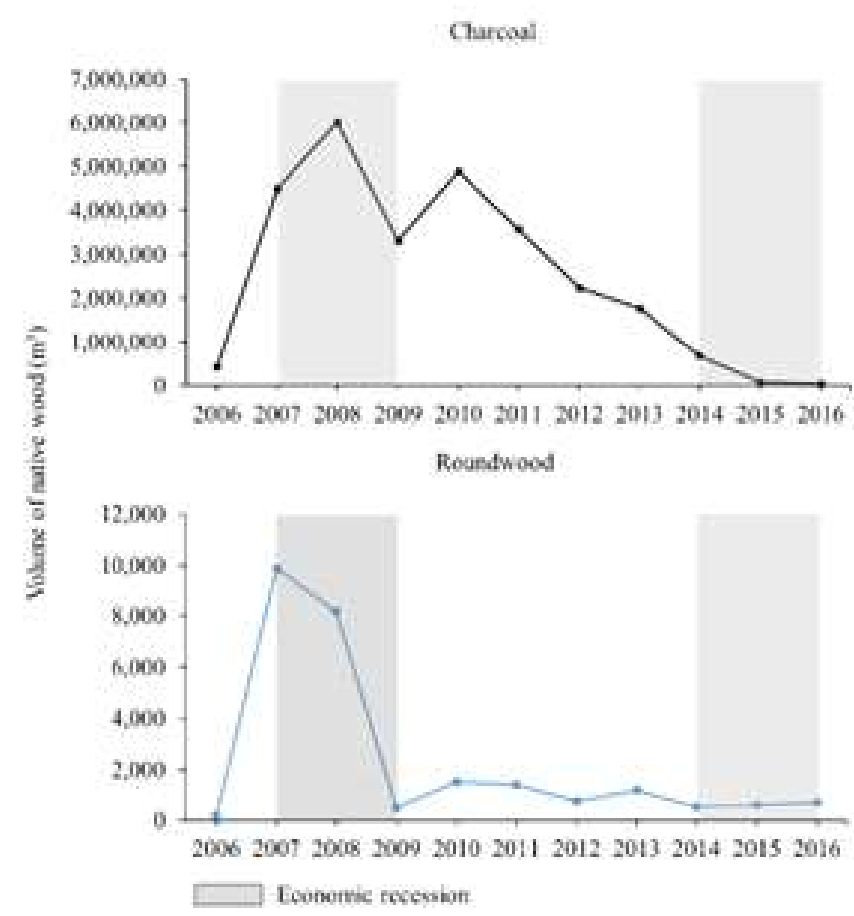

Figure 2 - Temporal dynamics of native wood destinated to Minas Gerais State, from 2006 to 2016.

Figura 2 - Dinâmica temporal da madeira nativa destinada ao Estado de Minas Gerais, de 2006 a 2016. $s s t=\sum_{i=1}^{n_{c}} \sum_{j=1}^{n_{i}} \sum_{k=1}^{n_{v}}\left(\mathrm{v}_{i j}^{k}-\mathrm{v}_{I}^{k}\right)^{2}$

where $n$ is the number of features; $n_{c}$ is the number of groups; $n_{i}$ is the number of features in group $i ; n_{v}$ is the number of variables used to group the features; $V_{I j}{ }^{k}$ is the value of variable $k$ of feature $j$ in group $i ;\left(\overline{V^{k}}\right)$ is the average of $k$; e $\left(\overline{V_{I}^{k}}\right)$ is the average of $\mathrm{k}$ in group $i$ (ESRI, 2019).

\subsubsection{Map production}

Spatial statistics results were presented as maps. Features were projected into Albers conical projection. For wood origin locations in Brazil, central meridian was $-55^{\circ}$ and standard parallels were $-1^{\circ}$ e $-27^{\circ}$. For the wood destination locations in MG State, central meridian was in $-45.45^{\circ}$ and standard parallels $-15.68^{\circ}$ and $-21.47^{\circ}$.

\section{RESULTS}

\subsection{Dynamics of the Brazilian native wood destined to Minas Gerais State}

The volume of native wood allocated to $\mathrm{MG}$ State market was about 31 million cubic meters from 2006 (when DOF started being used) to 2016. The
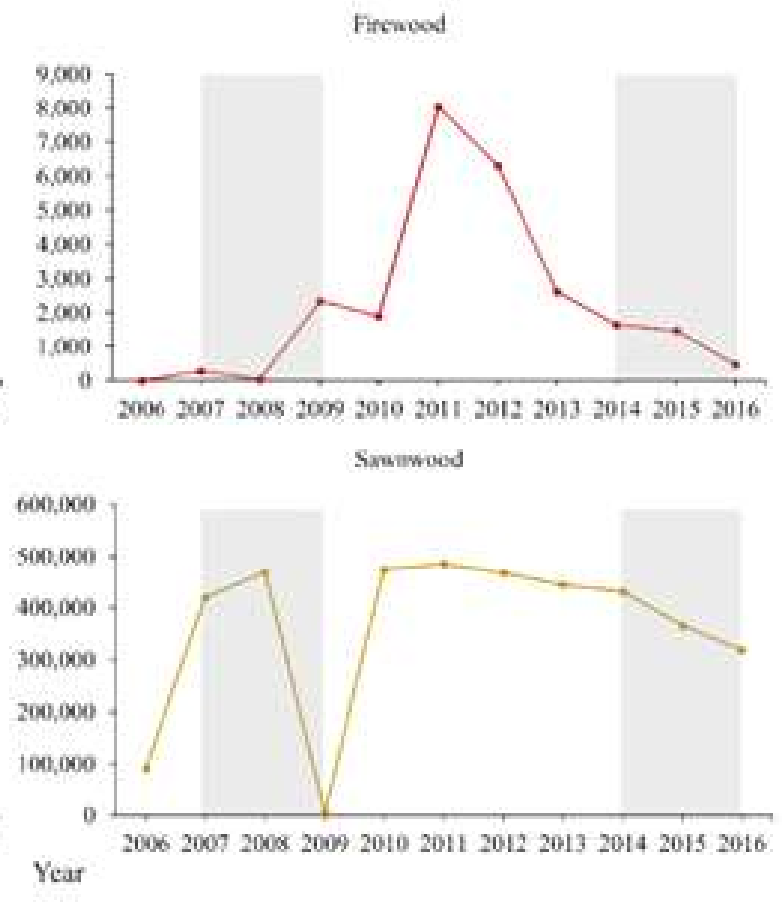

\section{Revista Árvore 2021;45:e4518}



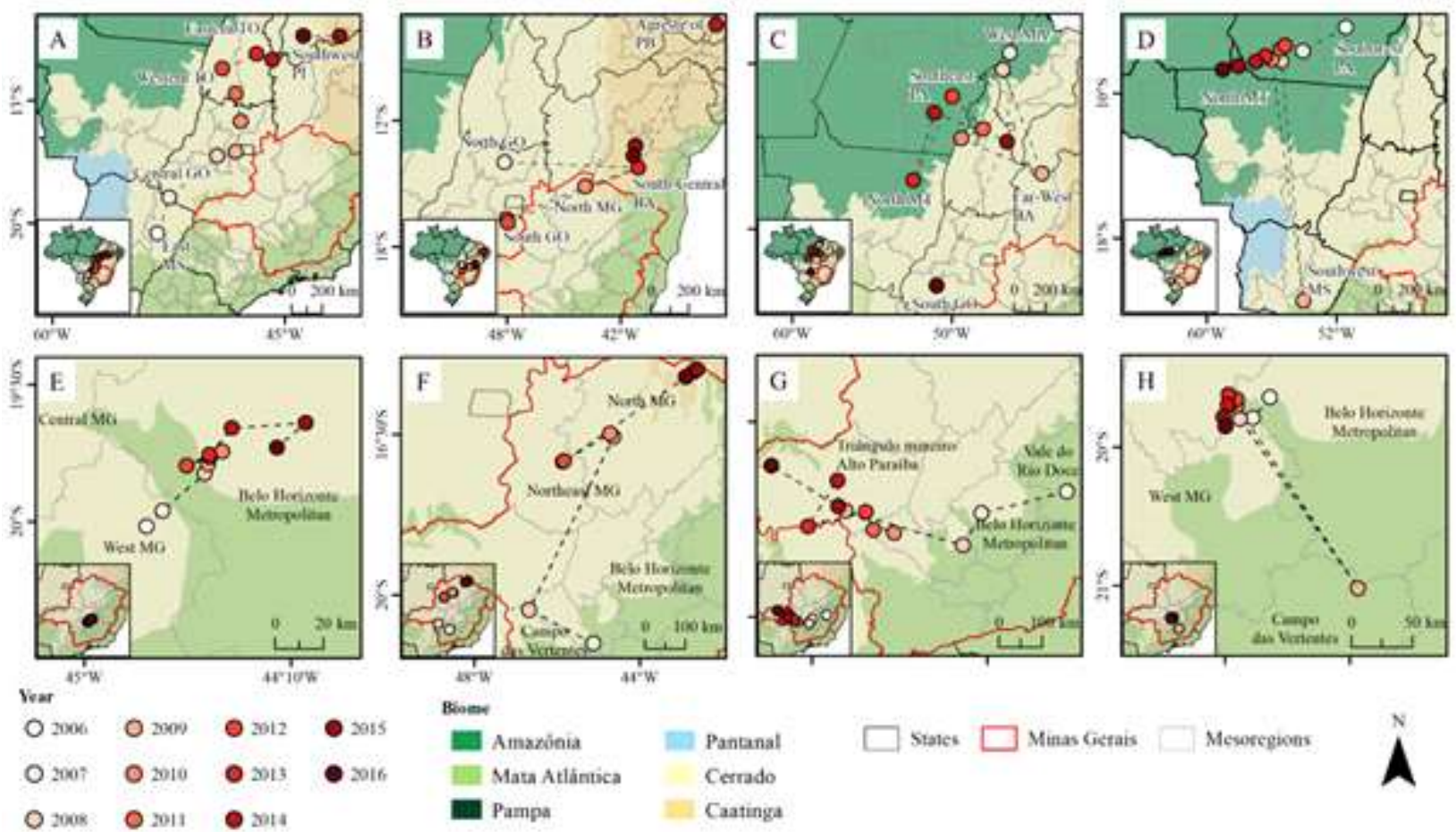

Figure 3 - Mean centers of native wood origin in Brazil (A: charcoal; B: firewood; C: roundwood; D: sawn-wood) and destination in Minas Gerais State (E: charcoal; F: firewood; G: roundwood; H: sawn-wood). BA: Bahia State; GO: Goiás State; MA: Maranhão State; MS: Mato Grosso do Sul State; MT: Mato Grosso State; MG: Minas Gerais State; PA: Pará State; PB: Paraíba State; RO: Rondônia State; TO: Tocantins State.

Figura 3 - Centros médios de origem da madeira nativa no Brasil (A: carvão; B: lenha; C: madeira em tora; D: madeira serrada) e destino em Minas Gerais (E: carvão; F: lenha; G: madeira em tora: H: madeira serrada). BA: Estado da Bahia: GO: Estado de Goiás; MA: Estado do Maranhão; MS: Estado de Mato Grosso do Sul; MT: Estado de Mato Grosso; MG: Estado de Minas Gerais; PA: Estado do Pará; PB: Paraíba; RO: Estado de Rondônia; PARA: Estado do Tocantins.

main products derived from this wood were charcoal $(87 \%)$ and sawn wood (13\%). Trades in charcoal, roundwood and sawn wood significantly decreased between 2008 and 2009, with falls of 45, 94\% and $99 \%$, respectively. Specifically, the sawn wood market followed the economic cycles of expansion and recession, showing recovery in 2010 and a further decline after 2014 (Figure 2).

\subsection{Spatial analysis of the native wood origin}

The spatiotemporal change in the mean centers of native wood origin presented two different patterns: oriented for charcoal and sawn wood, and not oriented ("zigzag pattern") for firewood and roundwood (Figure $3 \mathrm{~A}$ to $3 \mathrm{D}$ ). Along the 11 years, charcoal and firewood production centers have moved from the Midwest region, in Cerrado biome, towards the Northeast of Brazil, in Caatinga biome, with firewood without a clear distribution pattern. The migration of round timber production centers occurred from the North Region, in Amazon biome, towards the Midwest, in Cerrado, without a clear distribution pattern too. For sawn wood centers, the shift was from North to Midwest region of Brazil, remaining in the Amazon biome for almost all years.

Grouping analysis of wood origin in Brazil was highly accurate $\left(\mathrm{R}^{2}>0.96\right)$. The production of charcoal and firewood in Midwest, North and Northeast regions of Brazil were defined as high and very high, mainly in the East of Mato Grosso do Sul State, South of Goiás State and South-Central of Bahia State mesoregions (Figure 4A to 4D). The high and very high production classes of roundwood and sawn wood were concentrated in the Midwest and North regions of Brazil. Specifically, the mesoregions Madeira-Guaporé, East of Rondônia State, Southeast and Northeast of Pará State, and North of Mato Grosso State were the most important solid wood 

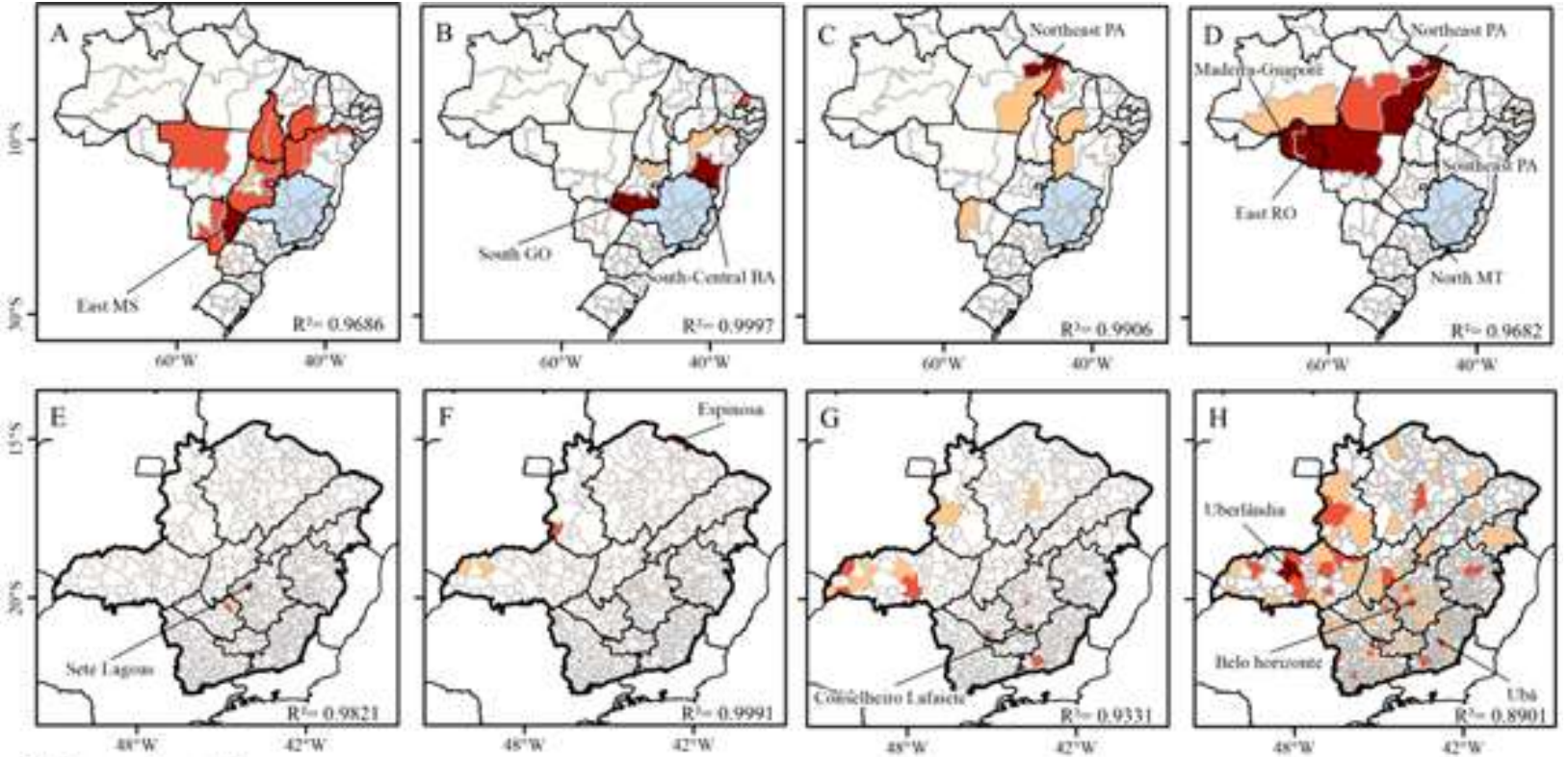

Volume of wood

Very high

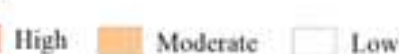

States

Mesoregions

Minas Gerais

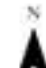

Figure 4 - Mesoregions groupings for native wood origin in Brazil (A: charcoal; B: firewood; C: roundwood; D: sawn-wood) and destination in Minas Gerais State (E: charcoal; F: firewood; G: roundwood; H: sawn-wood). BA: Bahia State; GO: Goiás State; MS: Mato Grosso do Sul State; MT: Mato Grosso State; PA: Pará State; RO: Rondônia State.

Figura 4 - Agrupamentos das mesorregiões de origem da madeira nativa no Brasil (A: carvão; B: lenha; C: madeira em tora; D: madeira serrada) e destino no Estado de Minas Gerais (E: carvão; F: lenha; G: madeira em tora; H: madeira serrada). BA: Estado da Bahia; GO: Estado de Goiás; MS: Estado de Mato Grosso do Sul; MT: Estado de Mato Grosso; PA: Estado do Pará; RO: Estado de Rondônia.

suppliers to MG State. Together, these mesoregions provided approximately 81 and $41 \%$ of all roundwood and sawn wood for the state, respectively (Table 1).

\subsection{Spatial analysis of the native wood consumption in Minas Gerais State}

The spatiotemporal change for native wood destination mean centers did not present an oriented pattern for any product (Figure $3 \mathrm{E}$ to $3 \mathrm{H}$ ). Spatial shifts in charcoal and sawn wood mean centers were relatively low (63 and $44 \mathrm{~km}$, respectively), remaining around the urban core of MG State: West and Belo Horizonte Metropolitan. For firewood and roundwood, mean centers have moved from West and Vale do Rio Doce to North and Triângulo Mineiro, respectively.

Regarding the grouping analysis of consumption sites $\left(R^{2} \geq 0.89\right)$, it was found that most charcoal and firewood were concentrated in a few municipalities within MG State (Figure 4E to $4 \mathrm{H}$ ). Remarkably, Sete Lagoas municipality consumed, approximately,
$36 \%$ of all native wood charcoal produced in this period. Demands for roundwood and sawn wood had a different pattern, with the highest consumption values being evenly distributed over geography. Municipalities of Belo Horizonte, Conselheiro Lafaiete, Uberlândia and Ubá stood out for the high demand of solid wood (Table 1).

\section{DISCUSSION}

\subsection{Dynamics of native wood supply in Brazil}

The native wood market destined to MG State experienced a significant decline, from 2006 to 2016. Several factors may have driven this reduction in wood consumption during this period, especially the economic downtrend (Köhl et al., 2015). The decrease in charcoal, roundwood, and sawn wood supply, especially from 2008 to 2009 , is consistent with this statement (Figure 2). Certainly, the 2008 global economic recession affected the forest sector in many developing countries (FAO, 2012; Arima et

Revista Árvore 2021;45:e4518 
Table 1 - Main suppliers and consumers of Brazilian native wood from 2006 to 2016.

Tabela 1 - Principais fornecedores e consumidores de madeira nativa brasileira de 2006 a 2016.

\begin{tabular}{|c|c|c|c|c|c|c|c|c|}
\hline & Region & State & Mesorregion & Charcoal & Firewood & Roundwood & Sawnwood & Total \\
\hline \multirow{16}{*}{ Suppliers } & \multirow[t]{3}{*}{ Midwest } & $\mathrm{GO}$ & - & $6,309,443$ & 11,505 & 457 & 4,125 & $6,325,529$ \\
\hline & & MT & - & $1,909,493$ & 0 & 669 & 553,033 & $2,463,194$ \\
\hline & & MS & - & $6,433,009$ & 0 & 1,700 & 18,396 & $6,453,104$ \\
\hline & \multirow[t]{5}{*}{ Northeast } & $\mathrm{BA}$ & - & $3,975,791$ & 11,960 & 1,448 & 795 & $3,989,994$ \\
\hline & & MA & - & 238,792 & 0 & 7,973 & 60,472 & 307,239 \\
\hline & & PB & - & 0 & 0 & 98 & 72,900 & 72,997 \\
\hline & & PI & - & $2,526,715$ & 50 & 1,916 & 217 & $2,528,897$ \\
\hline & & $\mathrm{RN}$ & - & 318,914 & 1,590 & 227 & 199 & 320,929 \\
\hline & \multirow{6}{*}{ North } & Others & - & 151,519 & 0 & 34 & 122 & 151,675 \\
\hline & & AM & - & 0 & 0 & 0 & 95,353 & 95,353 \\
\hline & & PA & - & 20,821 & 0 & 10,691 & $1,563,703$ & $1,595,215$ \\
\hline & & RO & - & 24,613 & 0 & 74 & $1,519,499$ & $1,544,184$ \\
\hline & & TO & - & $3,906,634$ & 0 & 52 & 4,948 & $3,911,634$ \\
\hline & & Others & - & 0 & 0 & 115 & 52.138 & 52.254 \\
\hline & \multirow[t]{2}{*}{ South } & PR & - & $1,297,660$ & 0 & 9 & 9,964 & $1,307,634$ \\
\hline & & Others & - & 356,737 & 0 & 21 & 18,673 & 375,431 \\
\hline Total & & & & $27,470,143$ & 25,104 & 25,483 & $3,974,535$ & $31,495,265$ \\
\hline \multirow[t]{12}{*}{ Consumer } & \multirow[t]{12}{*}{ Southeast } & MG & Campo das Vertentes & 175,750 & 0 & 273 & 110,233 & 286,256 \\
\hline & & & Central & 823,659 & 0 & 380 & 183,783 & $1,007,821$ \\
\hline & & & Jequitinhonha & 0 & 0 & 260 & 71,811 & 72,071 \\
\hline & & & $\begin{array}{l}\text { Belo Horizonte } \\
\text { Metropolitan }\end{array}$ & $14,558,618$ & 302 & 9,213 & 999,858 & $15,567,989$ \\
\hline & & & Northwest & 70 & 9,804 & 550 & 103,957 & 114,383 \\
\hline & & & North & 12,745 & 12,468 & 1,290 & 260,225 & 286,727 \\
\hline & & & West & $11,889,649$ & 0 & 1,566 & 266,201 & $12,157,417$ \\
\hline & & & South/Southwest & 1,435 & 916 & 2,196 & 498,673 & 503,218 \\
\hline & & & $\begin{array}{l}\text { Triângulo Mineiro/ } \\
\text { Alto Paranaíba }\end{array}$ & 312 & 1,383 & 5,540 & 838,963 & 846,198 \\
\hline & & & Vale do Mucuri & 0 & 0 & 405 & 34,784 & 35,189 \\
\hline & & & Vale do Rio Doce & 886 & 0 & 906 & 181,124 & 182,916 \\
\hline & & & Zona da Mata & 7,021 & 231 & 2,909 & 424,918 & 435,081 \\
\hline Total & & & & $27,470,143$ & 25,104 & 25,483 & $3,974,535$ & $31,495,265$ \\
\hline
\end{tabular}

al., 2014). In Brazil, an exploratory case study in the Amazon reported that this financial crisis significantly reduced native wood production, leading to a general unemployment in many forest-dependent regions (Canova and Hickey, 2012). The continuous decrease in native wood market after the crisis recovery, in 2010, may also be explained by the set of policies implemented by the Brazilian government, such as the internal wood market regulation, the creation of protected areas, the suppression of illegal deforestation and the definition of credit barriers to municipalities on deforestation edges (Lapola et al., 2014). As an example, two highly broadcasted operations carried out in 2008 resulted in the apprehension of nearly $20,000 \mathrm{~m}^{3}$ of illegally harvested logs (Arima et al., 2014). The advances in forest exploitation control and licensing strictness have contributed to an increasing change in the production system, expanding the opportunities to establish plantation areas with exotic species, such as those of Eucalyptus genus, which are especially replacing native wood species for charcoal production (IBGE, 2017).

Native wood consumption in MG State previous to the first economic recession (2007-2008) was considerably high, according to consumption dynamics from 2006 to 2016 (Figure 2). When applying the average central statistic, it is clear that during this period, the native wood origin mean centers were located in the Midwest and North regions of Brazil, corresponding to Legal Amazon and Cerrado areas (Figure 3). At that time, the country was at the end of an intense deforestation process driven by widespread agriculture and livestock expansion mainly in Cerrado and Amazon Regions, with peak years occurring between 1990 and 2000 (Lapola et al., 
2014; Souza-Rodrigues, 2019). From 2006 to 2016, the mean centers of charcoal and firewood origins have moved towards the Northeast region of Brazil. This change is consistent with the historical patterns of agricultural expansion. Until 2008, agricultural crops cultivation was concentrated in the South and Midwest regions and, later, moved towards the Northeast, mainly in Maranhão, Tocantins, Piauí, and Bahia States, region ordinarily called as "Matopiba" (Lima et al., 2019), becoming a new successful agricultural Brazilian frontier, mainly for soybean plantations. After 2009, the original mean centers for roundwood and sawn wood have significantly moved from the North to Midwest region of Brazil, possibly as a consequence of strong regulation concerning native timber exploration. Strict licensing control over forest exploration significantly restructured the timber industry leading to closure of several illegal or inefficient companies. This has favored other regions in the Midwest, like Mato Grosso State, in detriment of others in the North, like Pará State (Santos and Santana, 2009; Ribeiro et al., 2011).

The high accuracy of grouping analysis concerning supply and demand of native wood (expressed by $\mathrm{R}^{2} \geq 0.89$ ) indicates that the cluster analysis was effective in separating groups of wood producers and consumers (Wu et al., 2015). Regarding the origin sites, there was high charcoal production in the East of Mato Grosso do Sul State mostly due to deforestation by livestock purposes, which was stimulated by global demand and supportive government policies at the beginning of the decade (Fialho, 2014). The high production of firewood in Midwest and Northeast of Brazil, particularly in Bahia State, in turn, is a consequence of firewood dependence as an energy source for local domestic and economic purposes. Native biomass is relatively inexpensive in these regions, which favors its use as an alternative fuel (firewood) (Coelho Junior et al., 2018). The great production of solid wood in Madeira-Guaporé, East of Rondônia, Southeast and Northeast of Pará, and North of Mato-Grosso mesoregions is historically driven by the expansion of pastures and soybean plantations (Arima et al., 2011; Lima et al., 2019), associated with a traditional forestry sector leveraging the economy of many Amazonian municipalities (Ribeiro et al., 2011; IBGE, 2017).

\subsection{Dynamics of native wood demand in Minas Gerais State}

The spatiotemporal dynamics of native wood consumption in MG State is directly associated with the development of wood-demanding industries within the state. The mean centers of charcoal and sawn-wood were strongly influenced by the high consumption of Sete Lagoas and Belo Horizonte (capital) municipalities, where most of the points were concentrated over the years. Such pattern/behaviour demonstrates the large industries resilience when facing supply reduction after the economic recession. Furthermore, it also shows the efficiency in changing the production systems of forest plantations (Martins et al., 2018), and governmental programs to guarantee investments in civil construction in order to mitigate the crisis impacts (Young, 2012).

The grouping analysis regarding native wood demand shows distinct patterns when products related to energy (charcoal and firewood) are compared to solid wood (roundwood and sawn-wood). Energy consumption groups are located in the Center and North of MG State, while solid wood clusters are dispersed. In general, productive clusters are conditioned to a complex set of regional factors such as availability and costs of qualified workforce, connection with large markets and local technological progress (Kies et al., 2009; Li et al., 2020). In this research, the influence of regional factors on wood consumption was not studied, however, this may support extra explanation for the observed spatial pattern.

The main use of charcoal is for pig iron production, ferroalloy, and cement for civil construction (Fontes et al., 2005; Gomes et al., 2007). Consumption of this product in MG State was concentrated around Sete Lagoas and Divinópolis, precisely where pig iron, steel centers, and cement industries are located (Rezende et al., 2005). Firewood highest demands occurred close to origin centers in the Brazilian Northeast region, due to its low value-added, which does not justify its transport over long distances (Coelho Junior et al., 2018). The greater dispersion of solid wood consumer groups suggests an existence of small to medium primary wood processing industries in the state. The higher demand in some micro-regions, such as Belo Horizonte, Conselheiro Lafaiete, Ubá and Uberlândia

Revista Árvore 2021;45:e4518 
are explained for their importance as input suppliers (IBGE, 2008) and/or industrial potential, mainly concerning the furniture manufacturing sector (Bastos and Almeida, 2008).

\section{CONCLUSION}

This study provides crucial and previously inaccessible information to understand the forest sector in Brazil through spatial statistics application and historical data. This approach allowed us to show oscillations in native wood market, map spatial shifts and clusters for supply and demand, concerning roundwood, sawn wood, firewood and charcoal. Thus, historical dynamics may reveal the effect of forest-related factors, including economic recessions and control policies, whose effect suggests the gradual replacement of native wood production by planted forest in Brazil. The highly productive suppliers for native wood that have been identified, indicate the most suitable sites for upcoming forest policies concerning regional development, traditional market maintenance and deforestation control.

\section{AUTHOR CONTRIBUTIONS}

Conceptualization ideas - Thales Guilherme Vaz Martins, Geraldo Gonçalves dos Reis, and Maria das Graças Ferreira Reis.

Data curation - Alexandre Simões Lorenzon and Douglas Vinícius Vaz Martins.

Formal analysis - Thales Guilherme Vaz Martins, Rodrigo Vieira Leite and Lucas Arthur de Almeida Telles.

Methodology - Thales Guilherme Vaz Martins, Gleidson Guilherme Caldas Mendes, Mayara Ribeiro Lage, Dayane Lopes Pinto.

Investigation: Thamires de Souza Carvalho and Hiohanes Moura Cardoso.

Writing, review and editing - Thales Guilherme Vaz Martins, Geraldo Gonçalves dos Reis, and Maria das Graças Ferreira Reis.

\section{ACKNOWLEDGEMENTS}

This study was financed in part by the Coordenação de Aperfeiçoamento de Pessoal de Nível Superior - Brasil (CAPES) - Finance Code 001.

\section{REFERENCES}

Arima EY, Barreto P, Araújo E, Soares-Filho B. Public policies can reduce tropical deforestation: Lessons and challenges from Brazil. Land Use Policy. 2014;41(2014):465-73. http://dx.doi. org/10.1016/j.landusepol.2014.06.026

Arima EY, Richards P, Walker R, Caldas MM. Statistical confirmation of indirect land use change in the Brazilian Amazon. Environmental Research Letters. 2011;6(2).

Ayhan I, Mert Cubukcu K. Explaining historical urban development using the locations of mosques: A GIS/spatial statistics-based approach. Applied Geography. 2010;30(2):229-38. http://dx.doi. org/10.1016/j.apgeog.2009.05.002

Bastos SQ de A, Almeida BB de M. Metodologia de Identificação de Aglomerações Industriais: Uma Aplicação para Minas Gerais [Industrial Agglomeration Identification Methodology: An Application for Minas Gerais]. Revista Economia. 2008;9(4):63-86.

Bösch M, Weimar H, Dieter M. Input-output evaluation of Germany's national cluster of forestbased industries. European Journal of Forest Research. 2015;134(5):899-910. doi: 10.1007/ s10342-015-0898-7

Burkhard B, Kroll F, Nedkov S, Müller F. Mapping ecosystem service supply, demand and budgets. Ecological Indicators. 2012;21:17-29. doi: 10.1016/j. ecolind.2011.06.019

Canova NP, Hickey GM. Understanding the impacts of the 2007-08 Global Financial Crisis on sustainable forest management in the Brazilian Amazon: A case study. Ecological Economics. 2012;83:19-31. doi: 10.1016/j.ecolecon.2012.07.019

Coelho Junior LM, Martins K de L da C, Silva MVB da. Spatial convergence of the gross value of production of firewood in the mesoregions of the Brazilian Northeast. Revista Arvore. 2018;42(2). https://doi.org/10.1590/1806-90882018000200003

Curran SR, Sherbinin A de. Completing the picture: The challenges of bringing "consumption" into the population-environment equation. Population and Environment. 2004;26(2):107-31. doi: 10.1007/ s11111-004-0837-x

Revista Árvore 2021;45:e4518 
ESRI. ArcGIS Desktop. Version 10.6. Redlands, CA: Environmental Systems Research Institute; 2018. USA

Food and Agriculture Organization of the United Nations - FAO. State of the World 's Forests. Rome, Italy. 2012;60. [cited 2020 November 07]. Available from: www.fao.org

Fialho F. Mato Grosso do Sul 2000-2013. São Paulo: Fundação Perseu Abramo. Editora Perseu Abramo; 2014. [cited 2020 November 07]. Available from: https://fpabramo.org.br/publicacoes/wp-content/ uploads/sites/5/2017/05/MS-web.pdf

Fontes AA, Silva ML da, Lima JE de. Integração espacial no mercado mineiro de carvão vegetal. Revista Árvore. 2005;29(6):937-46. doi: 10.1590/ s0100-67622005000600013

Gomes MTMG, da Silva ML, Valverde SR, Jacovine LAG, Soares NS, Pires VAV. Diagnosis of the steel industry in Minas Gerais. Cerne. 2007;13:60-6.

Hart JF. Central Tendency in Areal Distributions. Economic Geography. 1954;30(1):48-59. doi: $10.2307 / 142234$

Instituto Brasileiro do Meio Ambiente e dos Recursos Naturais Renováveis- IBAMA. Informações do transporte e do consumo de produtos florestais 2007-2012. 2014. [cited 2020 November 07]. [cited 2020 November 07]. Available from: http://ibama.gov.br/phocadownload/dof/relatorios/ consolidados/relatorio-dof-2007-2012-final.pdf

Instituto Brasileiro de Geografia e Estatística - IBGE. Regiões de Influência das Cidades [Internet]. Rio de Janeiro, RJ, Brasil. 2008. [cited 2020 November 07]. [cited 2020 November 07]. Available from: https:// doi.org/https://biblioteca.ibge.gov.br/visualizacao/ livros/liv40677.pdf

Instituto Brasileiro de Geografia e Estatística - IBGE. Produção da Extração Vegetal e da Silvicultura. 2017. Rio de Janeiro: IBGE. 32, 1-8. [cited 2020 November 07]. Available from: https://biblioteca.ibge.gov.br/index.php/bibliotecacatalogo?view $=$ detalhes $\& \mathrm{id}=774$

Instituto Brasileiro de Geografia e Estatística - IBGE. Produção da Extração Vegetal e da Silvicultura [Internet]. 2018. Rio de Janeiro: IBGE. 33, 1-8. [cited 2020 November 07]. Available from: https:// biblioteca.ibge.gov.br/index.php/bibliotecacatalogo?view $=$ detalhes\&id $=774$

Kies U, Mrosek T, Schulte A. Spatial analysis of regional industrial clusters in the German forest sector. International Forestry Review. 2009;11(1):3851. doi: 10.1505/ifor.11.1.38

Köhl M, Lasco R, Cifuentes M, Jonsson Ö, Korhonen KT, Mundhenk P, et al. Changes in forest production, biomass and carbon: Results from the 2015 UN FAO Global Forest Resource Assessment. Forest Ecology and Management. 2015; 352:21-34. doi: 10.1016/j.foreco.2015.05.036

Lapola DM, Martinelli LA, Peres CA, Ometto JPHB, Ferreira ME, Nobre CA, et al. Pervasive transition of the Brazilian land-use system. Nature Climate Change. 2014;4(1):27-35. doi: 10.1038/ nclimate 2056

Lausch A, Heurich M, Fahse L. Spatio-temporal infestation patterns of Ips typographus (L.) in the Bavarian Forest National Park, Germany. Ecological Indicators. 2013;31:73-81. doi: 10.1016/j. ecolind.2012.07.026

Li C, Wu K, Gao X. Manufacturing industry agglomeration and spatial clustering: Evidence from Hebei Province, China. Environment, Development and Sustainability. 2020;22(4):2941-65. doi: $10.1007 / \mathrm{s} 10668-019-00328-1$

Lima M, Silva Junior CA da, Rausch L, Gibbs HK, Johann JA. Demystifying sustainable soy in Brazil. Land Use Policy. 2019;82:349-52. https://doi. org/10.1016/j.landusepol.2018.12.016

Martins BF, de Freitas ECS, Enriquez AG, Magalhães JG de S, Ribeiro CAASR, de Freitas JPO. Trajectory of the mass centers of Brazilian production of planted forests between 1990 and 2012. Advances in Forestry Science. 2018;5(3):42530. doi: $10.34062 /$ afs.v5i3.6464

Paetzold A, Warren PH, Maltby LL. A framework for assessing ecological quality based on ecosystem services. Ecological Complexity. 2010;7(3):273-81. doi: 10.1016/j.ecocom.2009.11.003

Rezende JLP, Coelho Junior LM, de Oliveira AD, Sáfadi T. Charcoal price analysis in four regions of

\section{Revista Árvore 2021;45:e4518}


Minas Gerais State-Brazil. Cerne. 2005;11(3):237-52.

Ribeiro ES, Sousa RAT de M e, Souza MD de, Dorval A, Costa RB da. Commercialization of wood from natural forests in the State of Mato Grosso from 2004 to 2009. Floresta e Ambiente. 2011;18(4):36575. doi: 10.4322/floram.2011.056

Santos RBN, de Santana AC. Comportamento recente do setor florestal madeireiro no estado do pará, Brasil [Recent behavior of the section forest lumberman in the State of Pará, Brazil]. Revista Arvore. 2009;33(3):533-43. https://doi.org/10.1590/ s0100-67622009000300015

Souza-Rodrigues E. Deforestation in the Amazon: A Unified Framework for Estimation and Policy Analysis. Review of Economic Studies. 2019;86(6):2713-44. doi: 10.1093/restud/rdy070

Syrbe RU, Walz U. Spatial indicators for the assessment of ecosystem services: Providing, benefiting and connecting areas and landscape metrics. Ecological Indicators. 2012;21:80-8. doi: 10.1016/j.ecolind.2012.02.013

Van Jaarsveld AS, Biggs R, Scholes RJ, Bohensky E, Reyers B, Lynam T, et al. Measuring conditions and trends in ecosystem services at multiple scales: The Southern African Millennium Ecosystem Assessment (SAfMA) experience. Philosophical Transactions of the Royal Society B: Biological Sciences. 2005;360(1454):425-41.

Wang SY, Liu JS, Ma TB. Dynamics and changes in spatial patterns of land use in Yellow River Basin, China. Land Use Policy. 2010;27(2):313-23. doi: 10.1016/j.landusepol.2009.04.002

Wu Z, He HS, Yang J, Liang Y. Defining fire environment zones in the boreal forests of northeastern China. Science of the Total Environment. 2015;518-519:106-16. doi: 10.1016/j. scitotenv.2015.02.063

Young C. Setor financeiro: suporte fundamental de transição para a economia verde. Rio de Janeiro, RJ: Fundação Brasileira para o Desenvolvimento Sustentável-FBDS. 2012. doi: 10.13140/ RG.2.1.1541.2563

Yue TX, Liu JY, Jørgensen SE, Ye QH. Landscape change detection of the newly created wetland in Yellow River Delta. Ecological Modelling. 2003;164(1):21-31. doi: 10.1016/S03043800(02)00391-5 